\title{
INVESTIGAÇÃO GEOFÍSICA 2D E 3D COM APLICAÇÃO EM MEIO AMBIENTE: ESTUDO SOBRE UMA ÁREA DE DISPOSIÇÃO DE RESÍDUOS DE ÓLEO LUBRIFICANTE NO MUNICÍPIO DE RIBEIRÃO PRETO-SP
}

\author{
Alexandre Lisboa Lago \\ Orientador: Dr. Vagner Roberto Elis (IAG-USP) \\ 194 p. - Tese (Doutorado) - Defesa 18.06.2009
}

\begin{abstract}
RESUMO. A geofísica tem mostrado eficácia em identificar áreas contaminadas por derivados de petróleo, contribuindo para tornar mais efetivos os programas de sondagem voltados à coleta de amostras e instalação de poços de monitoramento. 0 presente trabalho apresenta resultados de investigações geofísicas em uma área de disposição de resíduos de re-refino de óleo lubrificante localizada no município de Ribeirão Preto, no Estado de São Paulo. Na área de estudo os resíduos foram dispostos em quatro cavas com um volume total de aproximadamente $25.000 \mathrm{~m}^{3}$. Esta área está situada nos domínios geológicos dos derrames basálticos da Formação Serra Geral e arenitos da Formação Botucatu. As cavas foram totalmente preenchidas com resíduos por aproximadamente 25 anos e não foi usado nenhum tipo de impermeabilização na base e laterais destas cavas. 0 objetivo do trabalho foi 0 estudo de uma metodologia geofísica de aquisição e modelagem de dados 3D com os métodos da eletrorresistividade e polarização induzida para a caracterização geoambiental da área de estudo, seguido pelos métodos potencial espontâneo e ground penetrating radar (GPR). A aquisição de dados 3D, a partir de uma série de levantamentos elétricos 2D, mostrou-se eficaz em mapear variações de resistividade e cargabilidade em três dimensões, mostrando em subsuperfície o comportamento dos contaminantes. As anomalias condutivas na zona saturada e zona não saturada estão relacionadas à contaminação gerada pelo processo de biodegradação. Em geral, as cavas com resíduos são caracterizadas por baixos valores de cargabilidade. Nos levantamentos elétricos 2D são observadas anomalias condutivas abaixo das cavas coincidentes com a atenuação do sinal eletromagnético do GPR, evidenciando a contaminação do meio, bem como 0 aumento da polarização à medida que se afasta da fonte de contaminação. 0 método potencial espontâneo possibilitou também o mapeamento da contaminação, que é associada às anomalias negativas de potencial espontâneo e evidencia atividade geoquímica no local. 0 GPR foi o método mais eficiente na identificação da geometria das cavas, com exceção da cava 1, cuja base não é bem caracterizada pelo sinal GPR. As análises diretas de amostras de solo e água subterrânea confirmam a contaminação. Nas análises de solo, baixas concentrações de alguns hidrocarbonetos policíclicos aromáticos foram encontradas, principalmente naftaleno e fenantreno. Nas amostras de água, foi confirmado contaminação da água subterrânea por chumbo (Pb). 0 processo de biodegradação é confirmado pela existência de microorganismos (bactérias), como constatado na análise biológica das amostras de solo coletadas em um ponto específico, onde assinaturas geofísicas sugerem contaminação. Os métodos geofísicos utilizados afirmam-se como uma ferramenta de grande potencial na caracterização geoambiental, juntamente com os métodos de investigação direta neste caso de estudo, e podendo ser aplicados no estudo de áreas similares.
\end{abstract}

ABSTRACT. Geophysics has been shown to be effective in identifying areas contaminated by oil products, contributing to the greater efficiency of soundings programs and the installation of monitoring wells. The present work presents results of geophysical investigations in a lubricant oil waste area located in the municipality of Ribeirão Preto, São Paulo State, Brazil. In the study area the waste was disposed of in four trenches with a total volume of about $25,000 \mathrm{~m}^{3}$. This area is situated on the geological domains of the basaltic spills of the Serra Geral Formation and the sandstones of the Botucatu Formation. The trenches were totally filled with waste over approximately 25 years and no protection liners were used in the bottom or laterals of the trenches. The goal of the study was the acquisition and modeling of $3 \mathrm{D}$ data with the electroresistivity and induced polarization methods for the environmental characterization of the study area, followed by self potential and ground penetrating radar methods (GPR). The acquisition of 3D data, from a series of $2 \mathrm{D}$ electrical surveys, was effective in mapping variations of resistivity and chargeability in three dimensions, showing in the subsurface the behavior of contaminants. The conductive anomalies in the saturated zone and unsaturated zone were related to contamination generated by the biodegradation process. In general, the trenches with waste were characterized by low values of chargeability. In 2D electrical surveys, conductive anomalies were observed below the trenches coincident with the attenuation of the electromagnetic signal of the GPR, indicating the contamination of the environment and increased polarization from the contamination source. The self potential method also allowed mapping of the contamination, which is associated with negative anomalies of self potential and evidence of geochemical activity in the locale. GPR was the method most efficient in the identification of the geometry of the trenches, except in the trench 1, in which the base is not delineated by a GPR signal. A direct analysis of the soil and groundwater samples confirmed the contamination. In the soil analysis, low concentrations of several polycyclic aromatic hydrocarbons were found, mainly naphthalene and phenanthrene. In the water samples, there was confirmed contamination of the groundwater by lead $(\mathrm{Pb})$. The biodegradation process was confirmed by the presence of microorganisms (bacteria), as evidenced in a biological analysis of soil samples collected at a specific point, where geophysical signatures suggested contamination. The geophysical methods used were an excellent tool for an environmental characterization, and together with the direct methods of investigation in this case study and can be applied in the study of similar areas. 
RBGf

\title{
INVESTIGAÇÃO DO USO DA NORMA L 1 NO AJUSTAMENTO DE REDES GRAVIMÉTRICAS RELATIVAS
}

\author{
Francismar Rimoli Berquó \\ Orientador: Dr. Mauro Andrade de Sousa (ON) \\ 90 p. - Dissertação (Mestrado) - Defesa 19.06.2009
}

\begin{abstract}
RESUMO. 0 objetivo deste trabalho é investigar 0 uso de um algoritmo de ajustamento baseado no Método da Soma Mínima (MSM), também conhecido como norma $\mathrm{L}_{1}$, em redes gravimétricas relativas. Como estudo de caso, foi utilizada a rede gravimétrica relativa implantada com 0 gravímetro LaCoste \& Romberg G61, onde foi testada a viabilidade do uso deste algoritmo. 0 MSM é baseado no critério de minimização da soma dos valores absolutos dos resíduos. Os resíduos são correções calculadas no ajustamento, a partir de um sistema de equações. Soluções desse sistema de equações podem ser obtidas através de equações normais ou pelo algoritmo computacional SIMPLEX, por exemplo. Na mesma rede gravimétrica foi executado um ajustamento clássico através do Método dos Mínimos Quadrados (MMQ), utilizando o modelo paramétrico, para obter uma solução que pudesse servir como base de comparação com a solução do algoritmo de ajustamento. Nesta investigação foram realizadas as seguintes etapas: (i) Realização do ajustamento com injunção mínima para calcular a precisão da rede gravimétrica em estudo; (ii) Utilização de um algoritmo de ajustamento via norma $\mathrm{L}_{1}$, representado por uma expressão de equações normais, baseado no método paramétrico, tomando os valores de gravidade das estações gravimétricas da International Gravity Standardization Net-1971 (IGSN71) como fixos; e (iii) Utilização de um número adequado de reprocessamentos, a partir dos valores de gravidade ajustados via norma $L_{1}$, para encontrar os valores dos desvios absolutos medianos. Esses reprocessamentos são realizações a partir de inclusão de erros aleatórios nos intervalos gravimétricos.
\end{abstract}

ABSTRACT. The proposed aim of the present work is to analyze the use of on adjustment algorithm based on the Least Sum Method (LSM), or $\mathrm{L}_{1}$ norm as it is sometimes known in adjustment relative gravity networks. As a case study, the gravity network established with for the LaCoste \& Romberg G61 meter was used to test the viability of the adjustment algorithm. The MSM is based on the criterion of minimizing the sum of the absolute values of the residuals. The solution of this system of linear observation equations can be obtained from normal equations or using a SIMPLEX Linear Programming algorithm either. A conventional Least Squares Method adjustment was performed to obtain a solution that could serve as the comparison base with the solution of the adjustment algorithm based on the MSM. For this research the following steps were carried out: (i) Using the minimum constraint adjustment to find the precision of the gravity network; (ii) Using an algorithm for adjustment by $L_{1}$ norm, represented by a closed analytical expression, based on parametric method, and taking the values of gravity of the gravity stations of the International Gravity Standardization Net-1971 (/GSN-71) as fixed; and (iii) Using an appropriate number of reprocessing from the values of gravity adjusted based $\mathrm{L}_{1}$ norm to find the values of median absolute deviations. These reprocessing are achievements from inclusion of random errors in the gravity intervals. 


\title{
MÉTOdOS ELÉTRICOS E ELETROMAGNÉTICOS NA AVALIAÇÃO DA CONTAMINAÇÃO DE AQUÍFEROS POR ATIVIDADES DE MINERAÇÃO E INDÚSTRIA DE CURTUME
}

\author{
Luiz Fernando Jorge da Cunha \\ Orientador: Dr. Olivar Antonio Lima de Lima (UFBA) \\ 116 p. - Tese (Doutorado) - Defesa 07.07.2009
}

\begin{abstract}
RESUMO. Este trabalho apresenta os resultados de imageamentos geofísicos obtidos com a aplicação de métodos elétrico e eletromagnético indutivo (EM34) para descrever a estrutura aquífera e eventual contaminação relacionadas a resíduos da mineração de sulfetos de cobre no distrito de Pilar, no Vale do Curaçá, Bahia, e de resíduos de curtume no município de Várzea Grande, Mato Grosso. Nos trabalhos desenvolvidos na região do Vale do Curaçá, foram empregados o método elétrico de resistividade e polarização induzida e o método eletromagnético indutivo. A área estudada tem uma extensão aproximada de $225 \mathrm{ha}$, com um total de 8,8km de perfis levantados, com a ocupação de 36 sondagens geoelétricas e 1.540 estações de medição EM. 0 levantamento eletromagnético foi realizado com o sistema EM-34 em linhas que se cruzam nas direções NE-SW e SE-NW. Neste trabalho foram utilizados espaçamentos entre as bobinas de 10, 20 e 40 metros, em condições de investigar profundidade efetiva de 7,5-15-30 e 60 metros, dependendo das configurações de dipolo horizontal DMH e vertical DMV. 0 levantamento elétrico foi realizado com o arranjo Schlumberger de eletrodos em SEVs, equiespaçadas entre 50 e 100m, com AB/2 máximo de 250m. Em estruturas cristalinas, como as observadas no Vale do Curaçá com uma litologia complexa, onde a presença de água normalmente está associada a fraturas e falhas nas rochas, a identificação de áreas potencialmente contaminadas por metais pesados, usando apenas o método de resistividade poderia ser extremamente dispendioso e de pouco alcance. Dessa forma, a utilização também do método eletromagnético indutivo pode ampliar a área de abrangência do estudo com baixo custo na execução. A interpretação dos perfis e mapas de condutividade/resistividade mostraram a presença de corpos condutivos alongados, que podem estar relacionados com a drenagem ácida proveniente da lagoa de rejeitos dos efluentes líquidos do processo de tratamento mineral. A área estudada em Mato Grosso insere-se regionalmente na denominada Depressão Cuiabana (Migliorini, 1999), compreendendo uma extensa área rebaixada (relevo de planície), com altitudes entre 150 a 200m, entre o Planalto dos Guimarães e a Província Serrana. Nesta região os perfis e mapas de condutividade aparente obtidos com o sistema EM-34 apresentaram valores acentuados, coincidindo com aqueles obtidos por Lannes (2002) realizando análise química da água em relação à presença de cromo. Os dados foram processados com a utilização dos programas RES2DINV, IPI2Win e SURFER que possibilitaram a geração de pseudo-seções de condutividade/resistividade. Nos dois casos estudados, foram utilizados procedimentos de inversão que possibilitaram identificar corpos condutivos alongados a profundidades que variaram de terreno para terreno. 0 conjunto de dados elétricos e eletromagnéticos, auxiliado pelas análises de propriedades petrofísicas, aliadas às informações geológicas do local, possibilitaram uma modelagem no sentido de identificar-se direções preferenciais de percolação da contaminação subterrânea dos aquíferos.
\end{abstract}

ABSTRACT. This work presents the results of a geophysical imaging obtained with the application of electrical and electromagnetic inductive methods (EM-34) to describe the aquifer structures and its possible underground contamination related to wastes from mining of copper sulfides in the district of Pilar, in the Curaçá valley, Bahia, and from tannery residues in the city of Várzea Grande, Mato Grosso. The work done at the Curaçá valley, employed electrical resistivity, induced polarization and electromagnetic inductive methods. The studied area has an extension of approximately 225ha with a total of $8.8 \mathrm{~km}$ of surveyed profiles. A total of 36 geoelectric sounding and the measurement of 1,540 EM stations. The EM surveys were conducted with the EM-34 electromagnetic system along intersecting in lines of directions NE-SW and SE-NW. This work was used spacing between the coils of 10, 20 and 40 meters, capable of investigation and 7.5-15-30 and 60 meters of effective depth, depending on the configurations of dipole DMH horizontal and vertical DMV. The survey electrical was carried out with the vertical electrical sounding (array Schlumberger) and profiling dipole-dipole, spaced from 50 and 100 meters with AB/2 maximum of 250 meters. In crystalline structures such as those seen in the valley of Curaçá, with a lithology complex, where the presence of water normally associated with the fractures and faults in the rocks, the identification of areas potentially contaminated with heavy metals, only through the method of resistivity could be extremely costly and of little reach. Thus the use of inductive electromagnetic method can enlarge the area scope of study with low cost in implementation. The interpretation of the profiles and maps of conductivity/resistivity showed the presence of conductive elongated bodies which may be associated with acid drainage from the waste lake of liquid effluents of the process of mineral processing. The area studied in Mato Grosso falls regionally in the within the so-called Cuiabana Depression, (Migliorini, 1999), including an extensive area lowered (relief plain), with altitude between the Plateau of Guimarães and Mountainous a Province. In this region the profiles and maps of apparent conductivity showed high values, coinciding with the values of the chemical analysis of water in relation to the presence of chromium made in previous work (Lannes, 2002). The data were processed using the software RES2DINV, IPI2Win and SURFER, which possibility the generation of pseudo-sections of conductivity/resistivity. In both cases studied, was used the process of reversal that allowed conductive elongated bodies at depths ranging from ground to ground. The set of electrical and electromagnetic data, aided by the analysis of petrophysical properties together the geological information of the local allowed modeling in order to identify directions preferential pathway to contamination of the aquifers. 
RBGf

\title{
PROCESSAMENTO E INTERPRETAÇÃO DE DADOS AEROGEOFÍSICOS NO NORTE DA FAIXA ARAÇUAÍ E ANÁLISE DE TRANSFORMAÇÕES MAGNÉTICAS NO DOMÍNIO DO ESPAÇO
}

\author{
Bruno Freitas Gonçalves \\ Orientador: Dr. Edson Emanoel Starteri Sampaio (UFBA) \\ 145 p. - Dissertação (Mestrado) - Defesa 29.07.2009
}

\begin{abstract}
RESUMO. Processamos e interpretamos dados aerogeofísicos magnéticos e gamaespectrométricos em uma área no extremo nordeste do cinturão móvel Araçuaí no Estado da Bahia, Brasil. Com o emprego de transformações do campo magnético no domínio da frequência correlacionadas às imagens de espectrometria gama, geramos mapas de interpretação que aprimoraram significativamente o conhecimento geológico e geodinâmico da área, que é 0 embasamento cristalino contíguo às bacias sedimentares tipo rift de Cumuruxatiba e Jequitinhonha. Além disso, analisamos técnicas de transformações no domínio do espaço por filtragens diferenciais adaptativas e B-spline cúbico tanto em dados obtidos de modelos teóricos como em dados reais. Os dados reais pertencem a uma quadrícula do mapa aeromagnético, que compreende uma anomalia dipolar isolada. Concluímos que essas técnicas têm determinadas vantagens em relação ao processamento no domínio da frequência para o cálculo de derivadas, tensores e continuações do campo.
\end{abstract}

ABSTRACT. We processed and interpreted airborne magnetic and gamma-ray spectrometry data in an area in the extreme northern range of the mobile Araçuai belt in the state of Bahia, Brazil. By employing transformations of the magnetic field in the frequency domain and correlated to gammaray spectrometry images, we generated maps of interpretation that improved significantly the geodynamical and geological knowledge of the area, which is the crystalline basement of the adjacent sedimentary rift basins of Cumuruxatiba and Jequitinhonha. Furthermore, we analyzed techniques for processing magnetic data in the space domain via adaptive differential filtering and cubic B-spline, both on theoretical model and real data. The real data pertain to a square on the aeromagnetic map, which comprise an isolated dipolar anomaly. We conclude that those techniques have certain advantages over processing in the frequency domain for the calculation of derivatives, tensors and continuations of the field. 


\title{
ALTIMETRIA POR SATÉLITE E GRAVIMETRIA MARINHA NA REPRESENTAÇÃO INTEGRADA DO CAMPO DE GRAVIDADE NA REGIÃO COSTEIRA DO BRASIL
}

\author{
Fernando Serrano Paolo \\ Orientador: Dr. Eder Cassola Molina (IAG-USP) \\ 73 p. - Dissertação (Mestrado) - Defesa 30.07.2009
}

RESUMO. A integração de dados de altimetria por satélite com dados de gravimetria marinha tem constituído uma importante ferramenta para a determinação precisa do campo de gravidade sobre a superfície do oceano. Esta abordagem vem sendo amplamente utilizada visto a grande densidade e disponibilidade dos dados derivados de sensores orbitais sobre a superfície do mar. Atualmente, um problema em aberto é a representação dos elementos do campo de gravidade com alta resolução em regiões costeiras, onde a medição de altimetria sofre degradação devido ao aumento da variabilidade da superfície do mar e presença da linha de costa. No presente estudo foram integrados dados de gravimetria marinha, provenientes do National Geophysical Data Center e levantamentos nacionais como o EQUANT I/II e o LEPLAC equatorial, com gradientes da superfície do mar derivados de altimetria por satélite das missões geodésicas Geosat/GM e ERS-1/GM. Utilizando-se o método da colocação por mínimos quadrados, que permite combinar dados de diferentes tipos com distribuição espacial heterogênea, foram calculados modelos de anomalia de gravidade ar-livre e altura geoidal para toda a região costeira do Brasil com uma resolução de 2'× 2'. A integração destes dois tipos de dados (satélite e navio) apresentou melhores parâmetros estatísticos nas regiões próximas da costa em relação ao modelo utilizando somente dados de satélite, sugerindo inclusive uma melhoria em relação aos modelos globais. Ainda, foi realizada uma avaliação da eficácia computacional do método da colocação por mínimos quadrados na integração de grandes conjuntos de dados. Este método se mostrou perfeitamente viável em termos de tempo de processamento, sendo ideal para se integrar a diversificada informação geodésica característica nas regiões de transição oceano-continente.

ABSTRACT. The integration of satellite altimetry data with marine gravity data has been an important tool for the accurate determination of the gravity field over the ocean. This approach has been extensively used due to the high density and availability of data derived from spaceborne sensors over the sea surface. Currently, an open problem is the representation of the gravity field elements with high resolution in coastal regions, where the altimetry measurement suffer from degradation due to the increased variability of the sea surface and the presence of the coast-line. In the present study were integrated marine gravity data, from the National Geophysical Data Center and national surveys as Equant I/II and equatorial LEPLAC, with sea surface gradients derived from the satellite altimetry geodetic missions Geosat/GM and ERS-1/GM. Using the least-squares collocation method, which can combine data of different type with heterogeneous distribution, were calculated models of free-air gravity anomaly and geoid height for the entire Brazilian coast with a resolution of 2' $\times 2$ '. The integration of these two types of data (satellite and ship) showed better statistical parameters in the coastal regions than using satellite data only, yet suggesting an improvement regarding the global models used for comparison. It was also conducted an assessment of the computational feasibility of the least-squares collocation method in the integration of large data sets. This method was quite feasible in terms of processing time, being the natural option to integrate the diverse geodetic information characteristic in regions of ocean-continent transition. 


\title{
AVANÇOS RECENTES NA DETERMINAÇÃO DAS ESTRUTURAS GEOLÓGICAS EM SUBSUPERFÍCIE DA PROVÍNCIA URANÍFERA LAGOA REAL (BA) A PARTIR DE DADOS AEROGEOFÍSICOS
}

\author{
Suze Nei Pereira Guimarães \\ Orientador: Dr. Valiya M. Hamza (ON) \\ 138 p. - Dissertação (Mestrado) - Defesa 30.07.2009
}

\begin{abstract}
RESUMO. Apresentam-se neste trabalho resultados de uma reavaliação recente de dados aerogeofísicos da província Uranífera de Lagoa Real (Bahia), adquiridos no Projeto São Timóteo. 0 propósito é contribuir com informações que permitam uma caracterização melhor das estruturas geológicas em subsuperfície, associadas às zonas de mineralização de Urânio nesta região. Neste contexto, os dados aeromagnéticos foram reprocessados, focalizando-se no uso criterioso das técnicas de derivada vertical, sinal analítico e deconvolução de Euler. Os conjuntos de lineamentos e feições estruturais determinadas no presente trabalho se encontram em boa concordância com o arcabouço estrutural inferido a partir das evidencias geológicas, mas significativamente diferentes daqueles apresentados no estudo anterior por Pascholati et al. (2003). Destacam-se, neste contexto, as delimitações das estruturas arqueadas na parte centro oeste da área de estudo, das feições circulares nas partes sul e sudeste e dos diversos lineamentos magnéticos na parte norte. Há indícios de que as mudanças nas direções dos lineamentos magnéticos estejam relacionadas com as zonas de fraturas e de cisalhamento e relacionadas com os locais de mineralização de Urânio. A grande parte dos corpos com contrastes magnéticos se encontra em profundidades menores que 500 metros, mas também há um número significativo de corpos em profundidades de até 1500 metros. Os resultados obtidos também permitiram delimitação de diversas feições estruturais, não identificadas nos levantamentos geológicos locais e nas análises anteriores de dados aerogeofísicos da área de estudo. Progressos também foram alcançados nas análises integradas das informações gama - espectrométricas, permitindo a identificação dos locais afetados por processos de metassomatismo e suas interrelações com as zonas de mineralização de Urânio.
\end{abstract}

ABSTRACT. In this work we present results of a recent analysis of air-borne magnetometric and gamma spectrometric data, acquired under the project São Timóteo, in the uranium province of Lagoa Real (BA). The main purpose is to provide additional insights into the magnetic and radiometric characteristics of the structural units in this region, associated with zones of Uranium mineralization. In this context, a detailed reevaluation of the aeromagnetic and radiometric data of the study area has been carried out, making use of such techniques as vertical derivative, analytic signal and Euler deconvolution. The results obtained are found to be in reasonable agreement with the local structural framework inferred from geologic studies, but significantly different from those reported in the earlier study of Pascholati et al. (2003). The results obtained have lead to identification of a large system of lineaments and basement features in the study area. Prominent among these are the large number of NW-SE trending lineaments in the northern parts, arc shaped features in the west-central parts and circular features in the south and south-western parts. There are indications that changes in direction of the lineaments are associated with fracture zones, associated with Uranium mineralization processes. Most of the bodies with magnetic contrasts are located at depths less than 500 meters, but there also a number of bodies at depths extending up to depths of 1500 meters. The results have also allowed determination of a number of structural features not identified in geologic studies as well as in previous interpretations of aeromagnetic data. Joint interpretation of magnetic and gamma spectrometric data have allowed identification of uranium mineralization zones, associated with local metasomatic processes. 


\title{
INVERSÃO GRAVIMÉTRICA DO RELEVO 3D DE BACIAS SEDIMENTARES E DA VARIAÇÃO DA DENSIDADE USANDO INFORMAÇÃO A PRIORI SOBRE $O$ AMBIENTE GEOLÓGICO
}

\author{
Cristiano Mendel Martins \\ Orientador: Dra. Valéria Cristina Ferreira Barbosa (ON) \\ 117 p. - Tese (Doutorado) - Defesa 31.07.2009
}

\begin{abstract}
RESUMO. Apresentamos dois métodos de inversão gravimétrica para estimar simultaneamente o relevo 3D do embasamento de bacias sedimentares e os parâmetros que definem uma presumida lei parabólica de decaimento do contraste de densidade com a profundidade no pacote sedimentar, conhecendo-se a priori as profundidades do embasamento em alguns pontos. Em ambos, os métodos de inversão, o pacote sedimentar é aproximado por uma malha de prismas 3D verticais justapostos em ambas as direções horizontais do sistema de destro de coordenadas. As espessuras dos prismas representam a profundidade do embasamento e são os parâmetros a serem estimados a partir dos dados gravimétricos. Para produzir uma estimativa única e estável das profundidades do embasamento, nossos métodos usam dois diferentes funcionais regularizadores impondo dois vínculos distintos. 0 primeiro, chamado suavidade global, impõe uma suavidade geral na estimativa do relevo do embasamento usando o regularizador de Tikhonov de primeira ordem, enquanto o segundo método de inversão, chamado de variação total, permite estimar relevos do embasamento descontínuos usando o regularizador variação total. Para estimar os parâmetros que definem o decaimento parabólico do contraste de densidade com a profundidade e produzir estimativa estável do relevo do embasamento, impomos um funcional regularizador às estimativas de profundidades do embasamento e impomos a proximidade entre as profundidades estimadas e profundidades conhecidas por furos de sondagens. Aplicamos a inversão com suavidade global a dados sintéticos de uma bacia sedimentar simulada, possuindo um relevo complexo do embasamento e duas seções sedimentares tendo duas diferentes leis parabólicas de variação do contraste de densidade com a profundidade. Os resultados mostram boas estimativas do relevo do embasamento e dos parâmetros da lei parabólica do decaimento do contraste de densidade com a profundidade. Além disso, aplicamos a inversão com variação total a dados sintéticos de uma bacia extencional simulada, possuindo arcabouço estrutural fortemente controlado por falhas. A inversão com variação total delineou bem todas as falhas. Ambas as inversões, suavidade global e variação total, foram aplicadas aos dados gravimétricos da parte continental e marinha rasa da Bacia de Almada, Bahia, Brasil. A inversão com suavidade global delineou feições geológicas no relevo do embasamento que não são diretamente inferidas através da simples inspeção da anomalia gravimétrica. A inversão com variação total mapeou não só as falhas com grande rejeito vertical que controlam as bordas da Bacia de Almada, mas também as falhas com pequeno rejeito que controlam as feições estruturais do arcabouço da Bacia de Almada.
\end{abstract}

ABSTRACT. We present two gravity inversion methods for simultaneously estimating the 3D basement relief of a sedimentary basin and the parameters defining a presumably parabolic decay of the density contrast with depth in a sedimentary pack assuming the prior knowledge about the basement depth at a few points. In both inversion methods, the sedimentary pack is approximated by a grid of 3D vertical prisms juxtaposed in both horizontal directions of a right-handed coordinate system. The prisms' thicknesses represent the depths to the basement and are the parameters to be estimated from the gravity data. To produce a unique and stable depth-to-basement estimate, our inversion methods use two different regularizing functionals imposing two different constraints. The first one, named global smoothness, imposes an overall smoothness on the estimated basement relief by using the first-order Tikhonov regularization, whereas the second inversion method, named total variation, allows estimating a discontinuous basement relief by using the total variation regularization. To estimate the parameters defining the parabolic decay of the density contrast with depth and produce stable depth-to-basement estimates we impose a regularizing functionals on the estimated basement depths and proximity between the depth estimates and known depths values at boreholes. We apply the global smoothness inversion to synthetic data from a simulated 3D sedimentary basin presenting a complex basement relief and two sedimentary sections having distinct parabolic laws describing the density contrast variation with depth. The results show good estimates of the basement relief and of the true parameters of the parabolic law of density contrast decay with depth. We also apply the total variation inversion to synthetic data from a simulated sedimentary extensional basin whose structural framework is strongly controlled by several faults. The total variation inversion delineates well all faults. Both the global smoothness and the total variation inversions are applied to real gravity data from the onshore and part of the shallow offshore Almada Basin, on Brazil's northeastern coast. The global smoothness inversion delineates geologic features in the basement relief that are not directly inferred just from inspection of the gravity anomaly. The total variation inversion maps not only the faults with large vertical slips controlling the Almada Basin borders, but also the faults with small vertical slips controlling the structural features on the Almada basement framework. 


\title{
OS MECANISMOS DE PROPAGAÇÃO E ATENUAÇÃO DE ONDAS SÍSMICAS EM ROCHAS RESERVATÓRIOS BASEADOS NA DINÂMICA DA POROELASTICIDADE
}

\author{
Francisco Henry Cabrera Zambrano \\ Orientador: Dr. Marco Antônio Barsotelli Botelho (UFBA) \\ 140 p. - Tese (Doutorado) - Defesa 31.07.2009
}

RESUMO. Um dos objetivos fundamentais da Geofísica de reservatórios é sua caracterização. Esta caracterização significa o conhecimento das propriedades petrofísicas das rochas e os fluidos contidos neles: a porosidade (capacidade de armazenamento de fluido), a viscosidade dos fluidos contidos e a permeabilidade da rocha. Em particular é de grande interesse o conhecimento dos valores da permeabilidade nas regiões do reservatório. A pergunta-chave neste contexto é: Pode-se fazer uma estimativa da permeabilidade do reservatório a partir dos dados sísmicos? Um dos primeiros geofísicos que formulou esta pergunta foi o cientista Maurice Biot nos anos 50 . Ele desenvolveu uma teoria sobre a propagação de ondas sísmicas em meios bifásicos ou porosos. Tal teoria é hoje aceita na comunidade científica e conhecida como a Teoria de Biot. Um dos resultados fundamentais desta teoria é demonstrar a existência de uma segunda onda compressional chamada de onda P lenta além da onda P normal, chamada no contexto da Teoria de Biot de onda P rápida. Biot introduz a ideia de que as ondas sísmicas induzem um fluxo de fluido nas rochas saturadas, que equilibra a pressão induzida pela onda. Baseado nesta ideia, Biot estabelece uma relação analítica, dependente da frequência da onda, entre a permeabilidade e a atenuação sísmica. Os experimentos de laboratório, de sonic log, croswell, de VSP e da sísmica de superfície mostram que as predições de Biot frequentemente subestimam os níveis de atenuação, principalmente para medições nas frequências baixas. Além disso, na Teoria de Biot se deduz que o pico de atenuação desloca-se às altas frequências quando a viscosidade do fluido que satura a rocha aumenta. Em termos da permeabilidade, o pico desloca-se às altas frequências quando esta permeabilidade decresce, resultado que contradiz também os experimentos. Nesta tese estuda-se os desenvolvimentos e extensões da Teoria de Biot, principalmente o chamado mecanismo mesoscópico desenvolvido recentemente, que concilia as abordagens de Biot com os dados experimentais. Os três mecanismos desenvolvidos são 0 de saturação parcial, sugerido inicialmente por White e formalizado nos trabalhos de Norris; o modelo de fraturas de Brajanoski e o modelo da dupla porosidade de Berryman et al. Mostra-se nesta tese a equivalência destes três enfoques por meio de experimentos numéricos. Estes mecanismos são também equivalentes ao desenvolvimento das equações de Biot num meio transversalmente isotrópico. Neste trabalho obtém-se expressões analíticas das velocidades das ondas de Biot, que propagam-se fundamentalmente nas duas direções principais: paralela ao eixo de simetria e perpendicular a este eixo. Os resultados mostram que a onda $\mathrm{P}$ lenta tem um comportamento muito diferente nas duas direções, isto mostra 0 caráter difusivo desta onda, principalmente nas baixas frequências, contribuindo com as perdas da onda $P$ normal. Os resultados em todos os casos são similares. Foram implementados algoritmos numéricos que resolvem numericamente as equações de Biot em sua forma original e também as equações que incluem os mecanismos de perdas por viscoelasticidade e por heterogeneidades na escala mesoscopica. Dois tipos de metodologia foram utilizados para resolver as derivadas espaciais das equações de movimento: 0 método das diferenças finitas e o chamado método pseudospectral. Compara-se as duas metodologias em relação aos erros numéricos da discretização. Observa-se que o método pseudospectral fornece melhores resultados que o método das diferenças finitas, no sentido de atenuar os erros da dispersão numérica. As equações de movimento são escritas como um sistema de primeira ordem, ou seja, num esquema esforço-pressão-velocidade da partícula. № caso da dupla porosidade se deduz as relações constitutivas dos esforços e as pressões nas duas porosidades com respeito às velocidades da partícula nas fases sólida e fluida, o que permite escrever as equações de movimento como um sistema hiperbólico de primeira ordem. Para as três ondas compressionais foram encontradas expressões analíticas para as velocidades com respeito aos volumes das porosidades primária e secundária (fraturas). Além disso, deduz-se que a atenuação da onda P rápida depende da fração de volume da porosidade secundária (fraturas); quanto maior as fraturas, maior a atenuação da onda P rápida, mostrando também que ao contrário do modelo da porosidade simples (a Teoria de Biot original) a onda P rápida tem atenuação maior que a onda $\mathrm{S}$. Finalmente mostra-se que a atenuação da onda $S$ neste modelo é quase independente do volume das fraturas. 
ABSTRACT. In Geophysics of reservoirs the knowledge of the petrophysical properties of rocks, such as porosity and permeability, as well as viscosity of the contained fluids in the rocks, is fundamental a characterization of the reservoir. Of particular interest is the knowledge of permeability in reservoir regions. The key question in this context is: Can permeability be determined from seismic data? One of the first geophysicist to formulate this question, in the fifties, was the scientific Maurice Biot. He developed a theory about the propagation of seismic waves in biphasic or porous media, this theory is today accepted by the scientific community and is known as Biot's Theory. One of principal results of the Biot's Theory is demonstrate the existence of a second compressional wave called $\mathrm{P}$ slow wave, besides as the normal $\mathrm{P}$ wave, called $\mathrm{P}$ fast wave in the context of Biot's Theory. Biot introduce the idea that seismic waves induce a flow of fluid in saturated rock and that this flow balances the pressure induced by the wave. Based on this idea, Biot establishes an analytical relationship, depending on the wave frequency, between permeability and seismic attenuation. Laboratory experiments, Sonic log, Croswell, VSP and seismic surface show that Biot's predictions underestimate attenuation levels, mainly for low frequency measurements. On the other hand, Biot's Theory predict that the attenuation peak is shifted to high frequencies when the viscosity of fluid that saturates the rock take more higher values, in terms of permeability, the peak shifts to high frequencies when a permeability decreases, this result also contradicts the experiments. This thesis develop the extensions of Biot's Theory, mainly so-called mesoscopic mechanics recent developed. The aforesaid mechanism reconciles Biot's formulation with experimental data. The three mechanisms analyzed in this work are those of partial saturation, initially developed by White and formalized by the works of Norris, the fractures model of Brajanosky and the double porosity model of Berryman et al. The equivalence of these mechanisms to the development of Biot's equations in a transversally isotropic media is too showed. Analytical expressions are obtained from speed of Biot's waves which are propagated in two main directions: parallel to the symmetry axis and perpendicular to it. The results show that the slow $\mathrm{P}$ wave behaves very differently in both directions, this illustrates the diffusive character of this wave, mainly at low frequencies, contributing to the losses of the normal $P$ wave. The equivalence of these methodologies is demonstrate through numerical experiments based in implemented algorithms to solve numerically the Biot's equations in their original form, as well as equations that include loss mechanism by viscoelasticity and loss due heterogeneity on the mesoscopic scale. The movement equations are written as a firstorder system, that is to say in a scheme effort-pressure-particle velocity. In the case of double porosity the constitutive relationship of the effort and pressure of the two porosities is deduced with respect to particle velocity of solid and fluid phases which allows the movement equations to be written as a first order hyperbolic system. For the three compressional waves of this model, analytical expressions were found for the propagation velocity of the waves in relation to primary and secondary porosity volumes. More over it is deduced that the attenuation of the first $P$ wave depends on the volume fraction of the secondary porosity (fractures); the bigger the fractures, the bigger the attenuation of the fast $\mathrm{P}$ wave, at the same time showing that on the contrary to simple porosity model (Biot's original Theory) the fast $\mathrm{P}$ wave has higher attenuation than the $S$ wave. Finally, it is shown that the attenuation of the $S$ wave is almost independent of the volume of the fractures. Two types of methodologies were used to resolve the spatial derivatives of movement equations: the method of finite difference and pseudospectral method. The two methodologies are compared in relation to numerical errors of discretization. The results show that the pseudospectral method gives better results than finite difference method, in the sense of attenuating the errors of numerical dispersion. 


\title{
SIMULAÇÃO NUMÉRICA DO CICLO DIÁRIO DE PRECIPITAÇÃO SOBRE A BACIA AMAZÔNICA DURANTE A ESTAÇÃO CHUVOSA
}

\author{
Cláudio Moisés Santos e Silva \\ Orientador: Dr. Saulo Ribeiro de Freitas (INPE) \\ 181 p. - Tese (Doutorado) - Defesa 10.08.2009
}

RESUMO. Ciclo diário é o modo de variabilidade do clima que responde primariamente às forçantes de superfície. Modelos numéricos apresentam deficiência em simulá-lo principalmente sobre áreas continentais durante o verão. № caso da Bacia Amazônica, mostra-se que o máximo de precipitação simulado é adiantado em cerca de quatro horas relativamente às observações. Assim, a presente pesquisa enfatiza a importância da formulação da Função de Disparo de Convecção (FDC) na simulação do ciclo diário de precipitação sobre a Bacia Amazônica. Neste sentido, implementa-se uma nova FDC na parametrização convectiva em uso no modelo regional BRAMS. Sobre a região do experimento TRMM-LBA (Rondônia, S0 da Amazônia), a versão original do modelo simula o máximo de precipitação às 1400 UTC (1000 HL). Após a implementação, 0 máximo simulado ocorre às 1800 UTC (1400 HL), enquanto as observações de um radar banda S mostram o máximo às 1900 UTC (1500 HL). Este resultado é função de dois fatores: (i) a nova FDC é acoplada aos fluxos de calor sensível e calor latente à superfície; (ii) a parcela ascendida adiabaticamente na atmosfera apresenta as propriedades bem misturadas da Camada Limite Atmosférica, ao contrário da versão original. Assim, há uma redução da Energia Potencial Disponível para a Convecção e consequente estabilização estática da atmosfera durante 0 início da manhã. Verificam-se também melhorias na simulação do ciclo diário em outras áreas da bacia. Por exemplo, em regiões costeiras, onde estudos observacionais mostram o máximo de precipitação durante o período noturno e início da manhã. Além disso, o modelo consegue representar de forma mais coerente a variabilidade intrassazonal da atividade convectiva sobre a Amazônia.

ABSTRACT. The diurnal cycle is the climatic mode directly modulated by surface forcing. Numerical models fail to simulate it, especially over the continental areas during the warm season. Previous studies show that in the Amazon Basin the maximum rainfall is simulated around four hours before to the one observed with rain gauges. Thus, this work emphasizes the importance of the Convective Trigger Function (CTF) formulation on the rainfall diurnal cycle over the Amazon Basin. In this sense, a new CTF is implemented in the convective parameterization used in the BRAMS regional model. Over the area of the TRMM-LBA experiment (Rondônia, SW Amazônia), the original version of BRAMS simulates the maximum rainfall at 1400 UTC (1000 LST); with the new CTF, the maximum is at 1800 UTC (1400 LST), while the S-band radar rainfall maximum is at 1900 UTC (1500 LST). This result is attributed to two factors: (i) the new CTF is coupled to the sensible and latent heat fluxes at surface; (ii) the reduction during the early morning of Convective Available Potential Energy due to the well mixing properties of the parcel. There are also improvements of the diurnal cycle simulation over other regions of the Amazon Basin; for example, in the Northern coast, where observational studies show maximum rainfall during nighttime and early morning. Further, the model simulates more coherently the intra-seasonal variability of the convection over Amazônia. 